\title{
Monoamine Oxidase Inhibitor
}

National Cancer Institute

\section{Source}

National Cancer Institute. Monoamine Oxidase Inhibitor. NCI Thesaurus. Code C667.

Any substance that inhibits monoamine oxidase (MAO), an enzyme that catalyzes the oxidative deamination of monoamines and plays a role in the inactivation of neurotransmitters. 